\title{
MOBILE-ASSISTED LANGUAGE LEARNING IN A UNIVERSITY CONTEXT IN VIETNAM: STUDENTS' ATTITUDES
}

\author{
Pham Thu Tra* \\ Faculty of English, Hanoi National University of Education, \\ Xuan Thuy, Cau Giay, Hanoi, Vietnam \\ Received 23 September 2019 \\ Revised 6 December 2019; Accepted 16 February 2019
}

\begin{abstract}
The study concerns the attitudes towards Mobile-assisted language learning (MALL) of the participants in a university. Using the mixed-method research design with survey questionnaire as the main data collection tool, the research gained some significant findings and successfully met the aims of the study. The findings from both qualitative and quantitative data reveal that the participants basically held positive attitudes towards the use of MALL inside classroom and towards MALL in general. It is suggested that MALL be adopted as a new approach in English language teaching and learning. Moreover, some measures should be taken to develop the digital literacy of both instructors and learners.
\end{abstract}

Keywords: mobile-assisted language learning (MALL), Mobile - learning (M-learning)

\section{Introduction}

Under the immense domain of technologybased language learning, Mobile Learning (M-learning) is a growing field of interest within the scholar communities. Cheon, Lee, Crooks, \& Song (2012, p. 124) indicated that compared to classroom-based computer learning, mobile learning has the possibility to extend the interaction beyond the classroom; thus, enhances individualized, contextualized, and informal learning. In addition, with the boom of online resources and abundant education applications, mobile technology provides novel opportunities for self-directed learning outside the class (Godwin-Jones, 2011). At the same time, until recently, smartphone and tablet users have been surprisingly ubiquitous among Vietnam population.

M-learning can be used in virtually almost every aspect of education, including language

Tel.: 84-359832132

Email:trathupham.hnue@gmail.com learning. Concerning the benefits of using mobile in language learning, Nguyen (2016) claims that the ownership of mobile and wireless devices offers learners more active participation in learning resources, and allows them to choose the activities that meet their personal needs. The positive of using mobile technologies in language learning rapidly attracts new users, which potentially offers new contexts for learning (Pachler, Bachmair $\&$ Cook, 2010). Therefore, it is urgent that the use of mobile assisted language learning (MALL) be studied carefully to enhance the process of teaching and learning language.

However, most research into this field has primarily focused on learners' vocabulary acquisition, \& language acquisition in general, listening and speaking skills in specific. (Wong \& Looi, 2010; O, 2015; Wang \& Shih, 2015; Hadi \& Emzir, 2016; Sila Ahmad, Armarego \& Sudweeks, 2017). Little attention has been paid to learning strategies despite their pivotal importance. To strengthen the process of MALL implementation, understanding and 
measuring learners' attitudes is vital because a favorable attitude shows greater probabilities that learners will accept this new trend. Besides, there is a lack of research on MALL in Vietnamese language teaching and learning context.

The attitude towards MALL framework is adapted from the works of Egly and Chaiken (1998), Van den Berg, Manstead, Van der Pligt, \& Wigboldus (2006), and Davis (1989; 1993), which are most commonly cited as the Affective-Behaviour-Cognitive model of attitudes. This study focuses on investigating the students' attitudes towards MALL when employing mobile devices to learn since MALL is a growing field which needs carefully studying to better aid the learning and teaching in Vietnam.

The study is expected to provide further understanding about the attitudes towards MALL of the students in B university when employing mobile devices to learn English. Therefore, some teaching and learning implications can be drawn out to better the process of language teaching and learning using mobile devices. Also, the study aims at enriching the literature regarding M-learning in general, and MALL in particular.

This research focuses on answering the following research question: What are the students' attitudes towards the use of mobile devices to learn English inside classroom?

\section{Literature Review}

\section{Attitudes}

A number of definitions of attitudes can be found in the literature, and these definitions are given based on the perspectives which the research look at attitudes. The works of Wise (1985) and Auzmedi (1991; 1992) measured attitudes from an affective and cognitive point of views. Later, Egly and Chaiken (1998) and Van den Berg et al. (2006) introduced "attitudes" with three basic components: cognitive; affective; and behavioral. This is one of the most cited models of attitudes and referred to as the ABC model of attitude.

The cognitive component refers to an individual's belief about the attitudinal object. Fishbein and Ajzen (1975) claim that the information which a person has about an object is called 'belief'. In his influential paper, Vishal (2014) concludes that 'the cognitive component is the storage section where an individual organizes the information' (p. 07). The affective component of attitudes refers to the emotional responses (liking/disliking) towards an attitude object. According to Vishal (2014), a person's attitude cannot be simply determined by their beliefs since the emotion and cognitive processes work spontaneously. According to Wicker (1969), the behavioral component which consists of actions or observable responses is a verbal or nonverbal behavioral tendency of an individual. It involves an individual's favorable or unfavorable behaviour to do something regarding attitude object. The cognitive component refers to the mental process of perception, conception and beliefs about the object. The affective component covers all the emotions and feelings such as: trust and distrust, like and dislike, etc. Lastly, the behavioral component is concerned with behavioral intention or action, behavior that demonstrates the future tendency to act in a specific way.

Accordingly, the main framework for attitude towards MALL still contains three main components: Cognitive, Affective and Behavioural. The first component - Cognitive not only deals with students' perceptions about the usefulness and ease of use when employing mobile devices to learn English, but also their perceptions about the difficulty they face when using mobile devices to learn English. The second component - Affective focuses on students' feelings when using mobile devices to learn: enjoyment, excitement, and anxiety. The last component - Behavioural provides information about the students' future 
decision over whether they want to keep using mobile devices to learn; whether they need guidance; etc. This framework is adapted from Technology Acceptance Model by Davis (1989) which described that attitude is the degree to which using technology is free of effort measures the perception of ease of use; the degree to which the technology can help to improve the task performance. However, this model does not fully fit the scope of this study - students' attitudes towards MALL since it mainly focuses on the perception of usefulness of the attitudinal subjects, but neglects the perceptions of difficulty. As a result, negative feelings such as anxiety are also not considered, which might not fully demonstrate the attitude of the participants. Therefore, the author has adapted this model combined with the $\mathrm{ABC}$ model to best fit the scope of her study: attitudes towards MALL and perception of its usefulness influences the intention to use a mobile device:

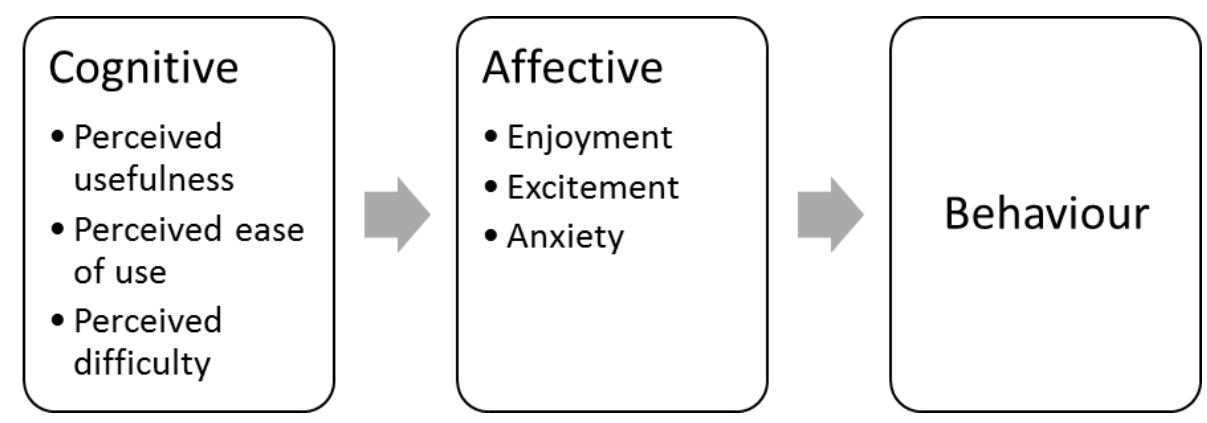

Figure 1. Theoretical framework for attitude towards MALL (Adapted from Technology Acceptance Model by Davis (1989))

Attitudes towards MALL

Studies by Fujimoto (2012), Hadi \& Emzir (2016), O (2015), Sila Ahmad, Armarego, \& Sudweeks (2017), Wang \& Shih (2015), White \& Mills (2011), Wong \& Looi (2010) share the same results that learners generally have positive attitudes towards the use of mobile devices to learn a language.

However, negative opinions are also presented in some studies. Participants in Motiwalla's (2017) study showed considerable disappointment with smartphones due to their small size screen, typing difficulty and unsatisfying quality of the visuals. Also, the results in Stockwell's (2010) study reveals that students would rather use laptops to learn vocabulary than smartphones, and $60 \%$ of the students in his study did not use smartphones to learn vocabulary.

\section{M-learning in higher education}

M-learning has the possibility to support all forms of education ranging from primary to higher education; however, higher education is particularly more appropriate to adopt student-centered mobile learning (Cheon et al., 2012). The figures from Cheung's (2012) study prove the popularity of mobile devices among university students $(83 \%$ of students have the ownership of smartphones; $63 \%$ for notebook devices; only $2 \%$ of the students do not own any mobile devices). To gain more credibility to their research involving the suitability of mobile learning in higher education, Cheon et al. (2012) list a number of studies that have been done in university environment and harness supportive evidence. In spite of the need and the appropriateness of mobile learning in higher education, Cheon et al. (2012) also reveal that employing mobile learning in higher education is a complicated task facing complex technical problems and cultural challenges, which can be overcome by developing plans, such as design guidelines, development phases and considering the 
level of students' readiness and the teachers' readiness as well.

\section{MALL in Vietnam}

Concerning the level of student's readiness in Vietnam's language teaching context, Nguyen (2016) held a survey within the pool of participants from a university. The results reveal that most of the participants had the ownership of mobile phones, and $67 \%$ of them used these devices to learn a language. The survey results also show a positive perception from students about MALL. 35\% of the participants believed that the courses were very efficient, and $45 \%$ believed that the courses were efficient with the support of mobile learning. Nguyen (2016) concluded from his survey results that mobile learning can be appropriately applied within Vietnam teaching and learning language. However, when dealing with the attitudes of students towards MALL, Nguyen (2016) did not use any particular frameworks, which can somehow arouse doubts over the sufficiency of the study's results.

Most of the aforementioned studies show the usefulness of mobile technology for language acquisition. The participants in those studies are mostly students in university, and the main instruments are pre- and post-tests and interview and survey. Most reviewed papers examine vocabulary acquisition, listening and speaking skills, and language acquisition in general. Viberg and Gronlund (2012) concluded, 'very little attention is devoted to individuals' language learning strategies and learning styles when employing mobile devices for their language learning' (p.7). Besides, there has been a lack of research papers examining the application of MALL in classroom in Vietnamese contexts; only one has been done so far but did not employ any particular frameworks.

\section{Methodology}

A mixed methods research design is defined as a procedure for collecting, analyzing, and "mixing" both quantitative and qualitative methods in a single study to understand a research problem (Creswell \& Clark, 2011, p. 535). Therefore, this study can be categorized under the principle of a mixed methods research design since the findings are cultivated from both quantitative and qualitative data. Quantitative data yielding specific numbers which can be statistically analyzed can provide results to access the magnitude of trends and frequency. However, qualitative data from open-ended questions offer actual words of the people in the study, which offers better understanding over the research problem.

\section{Setting of the study}

The study was conducted in Faculty of English, B University in Hanoi, Vietnam. The faculty teaches various courses in English, but mostly focuses on educating teachers of English. It is notable that mobile has been used as a learning tool in many classes in this learning environment. Therefore, the students can use their mobiles for learning purposes inside classroom. However, there is no Wi-Fi free system in this learning context; the students have to use their own $3 \mathrm{G} / 4 \mathrm{G}$ connections to get access to the Internet.

This study was conducted in the first semester of 2018 academic year.

\section{Participants}

95 freshmen in B University, Faculty of English aged between 18 and 20 are the main participants of the study. Their assumed English level is A2 in CEFR, and their target level after the first year is B1 in CEFR. The participants belong to generation Z, technology generation. These individuals were born in a decade following the widespread emergence of the World Wide Web; thus, the Z generation are more technologically advanced than previous generations, and also have had early access to technology. 
All the participants are learners in the classes where mobile has been used as a learning tool.

\section{Data collection tools}

The survey questionnaire consists of four sections: Basic information, Attitudes towards MALL inside classroom, Attitudes towards MALL in general. The survey questions were constructed based on Attitude Framework. Moreover, the survey questions were also built based on $\mathrm{ABC}$ model of attitude, and with reference to these of Alzubi and Singh's (2017) and Ghrieb's (2015) studies.

In the Basic information section, the participants were asked to provide information about their age, gender, and whether they own a mobile devices or not; types of mobile devices used.

Each of the next two sections contains 10 items; each item was assessed using a five-point Likert scale ( 1 = "strongly agree" and $5=$ "strongly disagree). There were two more open-ended questions which allowed participants to express their opinions more thoroughly.

The questionnaire was then designed on Microsoft form, and was posted on the faculty's Facebook group. A call for students' participation was made on the official faculty's Facebook group. There were 95 respondents answering the survey questions.

\section{Findings}

\subsection{Participants' information about mobile ownership and types of mobile devices}

As can be seen from the chart above, $96 \%$ of the informants have ownership of a smartphone; $3 \%$ and $1 \%$ of them use a mobile phone and tablet respectively. Compared to smartphones, mobile phones are not administered by any operating systems and are only restricted to certain basic functions such as calling and texting, etc. Reasonably, mobile phone has lost its popularity. $1 \%$ of the informants have ownership of a tablet. In terms of size, a tablet is smaller than a laptop, yet larger than a smartphone and mobile phone; a tablet is built with wireless and a variety of software applications. It can be concluded from this finding that smartphones are by far the most popular devices among the participants. This is understandable, for this device offers an enormous diversity of prices and types which can meet the demands of most individuals.

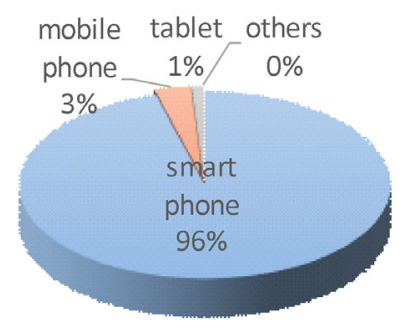

Graph 1. Types of mobile devices used

\subsection{Attitudes towards the use of MALL inside classroom}

\subsubsection{Cognitive}

Participants' perceived usefulness and ease of use about MALL inside classroom

There are three items in the survey questionnaire concerning the participants' perception about the usefulness and ease of use when using MALL as a learning tool inside classroom. Item S201 and Item S202 focus on the usefulness of MALL. Item S201 measures whether the informants agree that mobile devices can be used for learning purposes inside classroom. Item S202 provides information about whether mobile devices help enhance the collaboration inside classroom. Item S203 answers the question of whether the participants believe in the comfort of using MALL to learn inside classroom ease of use. The results for these items are presented in the table below: 
Table 1. Participants' perceived usefulness and ease of use about the use of MALL inside classroom

\begin{tabular}{|c|c|c|c|}
\hline Item & Mean & Mode \\
\hline S201 & I believe that mobile devices can be used for learning purposes \\
inside classroom. & 1.78 & 2 \\
\hline S202 & I believe that mobile devices can enhance collaboration inside \\
classroom. & 2.3 & 2 \\
\hline S203 & $\begin{array}{c}\text { I believe that it's comfortable to use mobile devices for learning } \\
\text { purposes inside classroom. }\end{array}$ & 23 & 2 \\
\hline
\end{tabular}

As can be seen from the table above, all three items have " 2 " as mode, which means that "agree" is mostly repeated in the answers of 95 participants. In Table 1, we see that the average score is 1.78 for the first item and 2.3 for the second item. These two statements concern the usefulness of mobile devices. The first item is evaluated as 1.78 which is between 1 (strongly agree) and 2 (agree). The second item's average score is 2.3 which is between 2 (agree) and 3 (neutral). From these results, it can be indicated that the participants generally believe in the usefulness facilitated by mobile devices inside classroom. The third item concerns the ease of use of mobile devices.
The average score for this item is 2.3 which is between 2 (agree) and 3 (neutral), indicating the subjects basically take a positive attitude towards this view.

In conclusion, these findings indicate that the participants basically agree that MALL inside classroom is useful and comfortable to use.

Participants' perceived difficulty towards MALL inside classroom

Besides the perceived usefulness and ease of use, the participants were also asked to give their opinions about the difficulty of MALL inside classroom. There are two items, S204 and S205 in this part. The results for these items are presented below:

Table 2. Perceived difficulty towards MALL inside classroom.

\begin{tabular}{|c|c|c|c|}
\hline Item & Mean & Mode \\
\hline S204 & I believe that mobile devices are tool for distraction inside classroom. & 2.58 & 3 \\
\hline S205 & $\begin{array}{c}\text { I believe that it is difficult to use mobile devices to carry out learning } \\
\text { activities inside classroom. }\end{array}$ & 3.37 & 4 \\
\hline
\end{tabular}

The average score for the first item is 2.58 which is between 2 (agree) and 3 (neutral), indicating that the students generally believe that their learning in classroom might be distracted by the use of mobile devices. Besides, the mode for this item is 3 , which means that the majority of participants chose "neutral" for this item. Moreover, participants were asked about whether it is difficult to use mobile in classroom or not, and the average score was 3.32 which is between 3 (neutral) and 4 (disagree) and also the majority of the participants answered "Disagree", which shows that the students basically are not in favor of this opinion.

In short, the participants generally have positive Cognitive towards the use of mobile devices as learning tools inside classroom. However, these Cognitive can be further reinforced if the participants' concern over the distraction of mobile devices can be mitigated.

\subsubsection{Affective}

There are three items in the survey questionnaire concerning the participants' feelings over the use of MALL inside classroom. The two first items, S206, and S207, focus on the positive feelings, namely, enjoyment; and excitement. The last item, S208, concerns the negative one: anxiety. The following table shows the results for these three items: 
Table 3. Participants' affective towards the use of MALL inside classroom

\begin{tabular}{|c|c|c|c|}
\hline Item & Mean & Mode \\
\hline S206 & $\begin{array}{c}\text { I enjoy using mobile devices to carry out learning activities inside } \\
\text { classroom. }\end{array}$ & 2.18 & 2 \\
\hline S207 & $\begin{array}{c}\text { I feel more excited when my teacher assigns works/tasks to do on mobile } \\
\text { devices. }\end{array}$ & 2.11 & 2 \\
\hline S208 & $\begin{array}{c}\text { I feel anxious when I have to use my mobile devices to do works/tasks } \\
\text { assigned by my teacher inside classroom. }\end{array}$ & 3.33 & 4 \\
\hline
\end{tabular}

As can been seen above, the average scores are 2.18 and 2.11 for S206 and S207 respectively. Both items are evaluated as between 2 (agree) and 3 (neutral); the mode of both items is 2 , which means that the number of participants choosing "Agree" outnumbers other options. These reveal that generally the informants had enjoyment and excitement when using mobile devices to learn. When asking whether the participants feel anxious when using mobile devices to learn inside classroom, most participants answer "Disagree" - mode is 4 (Disagree). The average score for S208 is 3.33 which is between 3 (Neutral) and 4 (Disagree). This means that the statement in S208 was basically not approved of.

Thesefindings indicate that the participants generally hold positive feelings towards the use of MALL inside classroom. The results from Table 3 show that most participants did not express negative feelings such as anxiety in the utilization of these devices to learn.

\subsubsection{Behavior}

The two last items S209 and S210 concern the participants' future behavioral tendency. S209 gives information about whether the participants will participate more in class if they can use mobile devices to learn. The last item S210 asks for the participants' opinion on whether they need certain guidance or recommendation from their instructors in using mobile devices to facilitate language learning. The following table displays the results for these items:

Table 4. Participants' future behaviors

\begin{tabular}{|c|c|c|c|}
\hline Item & Mean & Mode \\
\hline S209 & I will participate more if I can use mobile devices inside classroom. & 1.84 & 2 \\
\hline S210 & $\begin{array}{c}\text { I will need guidance from my instructors to better use mobile devices } \\
\text { inside classroom. }\end{array}$ & 1.67 & 2 \\
\hline
\end{tabular}

It is clear that both items' mode is 2, which reveals that for both items the majority of participants chose "Agree". Both items are evaluated as between 1 (Strongly agree) and 2 (Agree). This indicates that the subjects basically take a positive outlook in these views.

From these findings, it can be concluded that the utilization of MALL inside classroom encourages increased participation among participants. Besides, the instructors should give certain guidance in using mobile devices to facilitate language learning.

In the questionnaire, the students were asked:
"What do you think of using mobile devices for learning purposes inside classroom?"

This question was addressed to students in an open-ended format. The aim of this question was to cultivate more qualitative data since other questions in the questionnaires were in form of closeended items. There were 79 respondents who answered this question in total; 16 left blank space. After reviewing and analyzing participants' answers, it was found that the participants were mostly in favor of the use of MALL inside classroom. The 79 answers are classified in the table follow: 
Table 5. Qualitative Findings: Participants' attitudes towards the use of mobile devices for learning purposes inside classroom.

\begin{tabular}{|c|c|c|}
\hline \multirow{2}{*}{$\begin{array}{l}\text { Cognitive: } \\
\text { I think using mobile } \\
\text { devices inside } \\
\text { classroom is.... }\end{array}$} & Positive: & $\begin{array}{l}\text { useful; advantageous; necessary; convenient; creating stress-free } \\
\text { learning environment; making learning easier and more effective; } \\
\text { connecting students together; making learning more flexible; } \\
\text { making the lessons more appealing. }\end{array}$ \\
\hline & Negative: & making students distracted; hard \\
\hline \multirow{2}{*}{$\begin{array}{c}\text { Affective: } \\
\text { I feel ... when using } \\
\text { mobile devices } \\
\text { inside classroom to } \\
\text { learn }\end{array}$} & Positive: & excited; comfortable; motivating \\
\hline & Negative: & scared \\
\hline \multirow{2}{*}{$\begin{array}{l}\text { Behavior: } \\
\text { I will... }\end{array}$} & Positive: & $\begin{array}{l}\text { learn how to use mobile devices wisely inside classroom; need } \\
\text { guidance from my teacher. }\end{array}$ \\
\hline & Negative: & \\
\hline
\end{tabular}

As can be seen from the table above, the participants generally had more positive outlook towards the utilization of MALL for learnings purposes inside classroom than negative one. However, there was still a small number of respondents holding certain doubts towards these usages: feeling scare; being afraid of distraction; and finding it hard to use. Moreover, the participants also gave certain suggestions to better the use of MALL inside classroom:

- "Mobile devices shouldn't be used for tests".

- "The teacher should have some methods to control the class."

- "Mobile devices are suitable for group work."

"Are there any factors hindering the use of MALL for learning purposes inside classroom?"

This question was addressed to the informants to identify factors obstructing the use of MALL for learning purposes inside classroom. There were 70 participants responding to this question. Among these 70 respondents, 09 students answered "No"; 01 expressed their confusion by answering "I haven't thought about that"; the rest answered "Yes" for this question. In other words, about $85 \%$ (60 out of 70 ) of the respondents believed that the use of MALL for learning purposes inside classroom was hindered by certain factors.

The participants were also asked to clarify their answers by addressing these factors which were summarized below:

- Distraction: The participants listed down certain things they could do on the phone such as: using social media; playing games; etc., which caused their distraction.

- Lack of Internet connection: it is notable that there was no $\mathrm{Wi}-\mathrm{Fi}$ connection within campus.

- Unstable Internet connection: The participants explained that they had to use their own $3 \mathrm{G} / 4 \mathrm{G}$ connection which was normally unstable to use for a long time.

- Unclear teacher's instructions: Some participants revealed that since they had to use their phones to finish certain learning tasks in class, which was fairly new to some of them. However, the way teachers gave instructions was sometimes not really clear, and sometimes confused the students.

\subsection{Participants' overall feeling towards the use of MALL inside classroom}

From the findings, it can be concluded 
that the participants generally hold positive cognitive, positive affective, and positive behaviors towards the utilization of MALL for learning purposes inside classroom. This can be seen as PPP triode in Vishal's (2004) attitude triode.

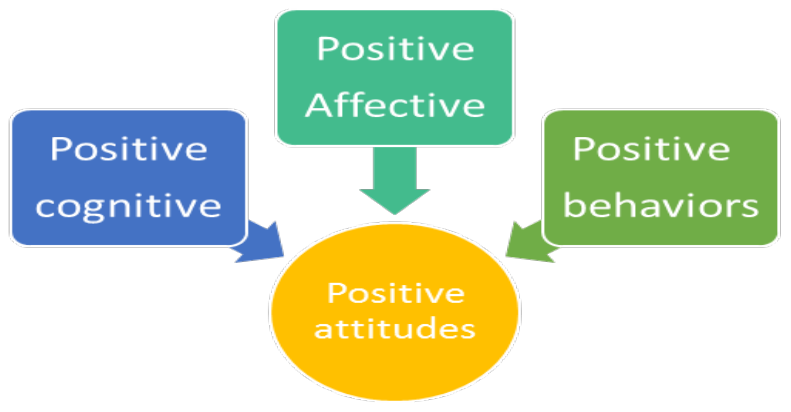

Figure 2. PPP attitude triode

This was the situation in which the participants not only had positive beliefs over the use of MALL, but also had positive feelings; therefore, their final responses were culminated as favorable. Accordingly, the participants' attitudes towards the use of MALL as learning tools inside classroom were positive. To better understand the students' attitudes towards MALL and to further clarify the reliability of the findings, some interviews with participants were made. The students' cognitive, affective, and behavioural attitudes could be shown in the following excerpts.

\section{Cognitive:}

Participant 1: "I think that when the teacher assigns tasks using mobile phone, the students are more motivated to learn"

Participant 2: "To me, using mobile phone makes the learning process quicker and more convenient"

Participant 3: "I think that the amount of knowledge that mobile phone can bring is really huge. Instead of buying so many books, having a mobile phone would be very time and money saving."

\section{Affective:}

Participant 3: "I feel so excited when I can play Kahoot! game that the teacher designed on my phone"

Participant 4: "My friends and I are really excited when we can use our mobile to do teachers' assignment in class"

\section{Behaviour:}

Participant 2: "I hope that I can use my phone more to study in my class"

However, some concerns over students' low digital literacy, and distractions were also revealed through the interviews as follows:

Participant 3: "When I was in schools, I had never got access to this new teaching method, and I was even prohibited to bring my phone to school no matter what purposes. As a result, when I first used mobile to learn in class in university, I was quite confused and lost."

Participant 4: "Sometimes, I find it quite hard to use some of the exercises on my mobile phones due to the fact that I have never done that before."

Participant 1: "When I was doing tasks on my phone, I got a message from Facebook. It was really annoying and distracting."

\section{Discussion}

An analysis of the survey data has been clearly illustrated above. Yet, some of the findings require further discussion.

The potentials of employing MALL inside classroom

It is worth mentioning that in Vietnamese teaching and learning context, using mobile inside classroom for learning purposes is considered relatively new. In fact, there exist 
some school regulations that the students are forbidden to use mobile phone inside classroom. Therefore, the majority of the students have little experience with it when reaching tertiary education. However, one potential of using MALL inside classroom is the popularity of these devices among the students. The findings show that $96 \%$ of the informants have the ownership of mobile devices. Compared to CALL, MALL is more affordable and convenient. Thus, if applied meticulously, these devices could become helpful learning tools.

Besides, the benefits of using M-learning in general, and MALL in particular have been discussed by many scholars. For instance, in order to fully understand the benefits of M-learning, Crompton (2013) comprehensively compared traditional learning and M-learning based upon a number of criteria. It can be concluded from Crompton's (2013) conclusion that compared to traditional learning, M-learning offers a decrease of limitations, a greater sense of flexibility, and an augmentation of learner-centered orientation. Mobile devices' popularity, together with their benefits in learning has shown great potentials of these devices in education.

Another factor contributing to mobile devices' potentials is the characteristics of the students. It is notable that the students belong to Generation Z - people who were born from 1995 onwards. One outstanding feature of Generation $\mathrm{Z}$ that differs from other generations is that Generation Z-ers are technology advanced, and they have access to mobile devices at early ages (Dolot, 2018). Therefore, it is necessary to provide Generation Z-ers with a more technologicallyfocused learning. Thus, the use of mobile devices to learn is inevitable.

Also, M-learning has the potential to support all forms of education ranging from primary to higher education; however, higher education institutions are particularly more appropriate to adopt student-centered mobile learning (Cheon et al., 2012). The suitability of mobile learning in higher education can be given credibility from the fact that the students in this learning level seem to have more selfdiscipline and be more responsible for their own learning process.

In short, mobile devices are highly popular among students at tertiary levels who are also most suitable to use mobile to learn. Besides, these students also belong to Generation Z, so they are used to using mobile devices from early ages. Additionally, M-learning and MALL have been proven to be advantageous by many scholars. As a result, mobile devices have potentials to become helpful learning tools.

\section{Worries over MALL}

From the findings above, it can be concluded that students generally have positive attitudes towards the use of mobile devices for learning purposes. However, the attitudes can be further reinforced if the students' worries can be mitigated.

The students have shown great worries over the fact that mobile devices can make them distracted from the lesson. Again, another characteristic of Generation Z-ers is short attention span (Dolot, 2018). Besides, there are a number of distractions such as social media, texting, games, etc. available on the mobile phone. Therefore, it is understandable why this worry exists. There should be some schemes or teaching methods in order to deal with this problem.

Besides the problems of distractions, the students also showed concern over the way teacher gave instructions. It is understandable that one challenge that teachers have to confront with mobile devices is the way to change their pedagogy to implement MALL. MALL is not only new for students, but also for the teachers. This struggle can be seen when they give instructions to guide students to perform certain tasks on mobile phone. Therefore, there should be some teacher's training over how to give instructions to provide students with better learning time. Maybe, due to the challenges in implementing 
MALL, the teachers in Liu and Cain's (2016) study preferred not to use mobile devices in their teachings. Therefore, in order to fully cultivate the benefits of MALL, teacher's pedagogical training is of great importance.

\section{Conclusion}

The development of technology has significantly changed virtually every aspect of life including education. Under the big domain of technology-based teaching and learning, MALL is a growing field which has been proved to be substantially advantageous. Moreover, mobile devices, especially smart phones have gained wide popularity. Understanding the pivotal importance of these devices in learning language, the author decided to carry out this study to examine the participants' attitudes towards MALL.

A survey questionnaire with 02 sections was made to meet the aims of the study. 95 participants participated in the survey. Using the mixed-method research design, the author has found certain significant findings.

Generally, the participants held positive attitudes towards the use of mobile devices insides classroom. Most of them perceived positive beliefs about the usefulness and ease of use of MALL. Besides, they also experienced the positive feelings of excitement when using mobile devices to learn language inside classroom. Therefore, it is understandable that their future behaviors of MALL are positive.

\section{Suggestions}

It is evident that the study could be more extendable if there were more participants in several contexts. This can help obtain more generalizable results.

Additionally, this study can be further elaborated by adding the analysis of teachers' attitudes towards MALL, which can then be compared with these of the student. Thus, the attitudes towards MALL can be more extendable and comprehensible.
Moreover, the participants' attitudes can be further reinforced if their worries disappear. This can be done if the teachers or instructors can develop certain teaching methods or scheme to solve the problems of distraction. Besides, the use of MALL can be better if there were a more stable Internet connection inside classroom. More surprisingly, there should be some teacher's training over how to give instructions. Teacher's clearer and more concise instructions can lead to better learning time. Another thing teachers can do is organizing a workshop at the beginning of the course to give students proper guidance or some rules to better prepare them for the use of MALL inside classroom.

\section{Teaching implications}

The results of the study suggest Mobile Assisted Language Learning be adopted as a new approach in English language teaching and learning. The language learning process will be positively and beneficially affected if MALL is used and implemented in academic context properly. Language learners can be provided with opportunities to make the best use of their portable devices in language learning thanks to mobile devices and applications available on these devices. Moreover, it is necessary to carry out learning tasks using mobile devices regarding their popularity and students' characteristics (Generation Z). Therefore, it is suggested that certain measures should be taken by the lecturers to implement MALL successfully.

The application of ICT in teaching in general, or MALL in specific has certainly caused changes in teaching pedagogy and learners' autonomy. However, there might be teachers and students who fail to adapt to such quick changes. During the survey, most students claimed that they needed the guidance from their teachers or instructors. The fact that they did not have access to these new technologies further confirmed their need of instruction. Therefore, a workshop at the 
beginning of the course familiarizing students with the new technology should be conducted.

\section{Learning implications}

It is suggested that the students study more about the uses of mobile devices for learning purposes to raise their mobile literacy. Therefore, better use of mobile devices can be achieved.

Besides, learners should equip themselves with knowledge about the new technology by familiarizing with some interactive websites such as Padlet.com; kahoot.it; etc. Research regarding learning strategies to improve reading and writing skills using mobile devices should be conducted by the students. Therefore, the enhancement of the four skills in English can be accomplished.

Last but not least, the learners should be able to deal with the problem of distraction when using mobile devices to learn English themselves. Learners' autonomy should be further reinforced so that the potentials of using mobile devices can be absorbed.

\section{References}

Alzubi, A. A. F., \& Singh, M. K. M. (2017). The Use of Language Learning Strategies through Smartphones in Improving Learner Autonomy in EFL Reading among Undergraduates in Saudi Arabia. International Journal of English Linguistics, 7(6), 59. https://doi.org/10.5539/ijel.v7n6p59

Assad, C. A. R. (2017). Mobile Learning Conceptual Framework For Higher Education in Developing Countries. International Journal of Education and Information Technologies, 11, 12-18.

Auzmendi, E. (1991). Evaluacio'ndelasActitudesha cialaEstad'istica en Estudiantes Universitarios y Factores que las determinan. Universidad de Deusto, Bilbao.

Auzmendi, E. (1992). Las actitudes hacia la matema'tica-estad'istica en las ense nanzas medias y universitarias. Bilbao, Mensajero.

Brown, J. D. (2001). Using surveys in language progams. Cambridge, UK: Cambridge University Press.

Brown, T. (2003). The role of m-learning in the future of e-learning in Africa? Paper presented at the $21 \mathrm{st}$. ICDE World Conference.

Cheon, J., Lee, S., Crooks, S. M., \& Song, J. (2012). An investigation of mobile learning readiness in higher education based on the theory of planned behavior. Computers \& Education, 59(3), 1054-1064. https:// doi.org/10.1016/j.compedu.2012.04.015

Clayton, J. B. (2003). One classroom, many worlds: Teaching and learning in the cross-cultural classroom. Portsmouth, NH: Heinemann.

Creswell, J. W., \& Clark, V. L. (2011). Designing and Conducting Mixed Methods Research (2nd ed.). Los Angeles: Sage Publications.

Crompton, H. (2013). Mobile Learning: New Approach, New Theory. Handbook of Mobile Learning, 47-57.

Darrel, M. W. (2011). Using Technology to Personalize Learning and Assess Students in Real-Time. Brookings - Center for Technology Innovation.

Davis, F. (1993). User acceptance of information technology: system characteristics, user perceptions and behavioral impacts. International Journal of Man-Machine Studies, 38, 475-487.

Diallo, A. (2014). The Use of Technology to EnhanceThe Learning Experience of ESL Students (Master Thesis). Concordia University, Portland.

Dolot, A. (2018). The characteristics of Generation Z. https://doi.org/10.15219/em74.1351

Dörnyei, Z., \& Taguchi, T. (2010). Questionnaires in second language research: construction, administration, and processing (2nd ed.). New York: Routledge.

Fujimoto, C. (2012). Perceptions of mobile language learning in Australia: How ready are learners to srudy on the move? The JALT CALL Journal, 8(3), 165-195.

Georgiev, T., Georgieva, E., \& Smrikarov, A. (2004). M-Learning - a New Stage of E-Learning. Proceedings of the 5th International Conference on Computer Systems and Technologies, 1-5.

Ghrieb, E. B. (2015). Teachers and Students Attitudes Towards the Use of Mobile Assisted Language Learning: A case Study of Master One EFL Students and EFL Teachers at University of Mohamed Kheider of Biskra (Master Thesis). University of Biskra, Biskra.

Godwin-Jones, R. (2006). Mobile Apps for Language Learning. Language Learning \& Technology, 15, $2-11$.

Godwin-Jones, R. (2011). Emerging Technologies Autonomous Language Learning. Language Learning \& Technology, 15(3), 4-11.

Hadi, M. S., \& Emzir, E. (2016a). Improving English Speaking Ability through Mobile Assisted Language Learning (Mall) Learning Model. IJLECR International Journal of Language Education and Culture Review, 2, 71-74. https://doi.org/10.21009/ ijlecr.022.09

Hadi, M. S., \& Emzir, E. (2016b). Improving English Speaking Ability through Mobile Assisted Language Learning (Mall) Learning Model. IJLECR International Journal of Language Education and Culture Review, 2(2), 71-74. https://doi. org/10.21009/IJLECR.022.09 
Harper, B. (2018). Technology and Teacher-Student Interactions: A Review of Empirical Research. Journal of Research on Technology in Education, 50(3), 214-225. https://doi.org/10.1080/15391523. 2018.1450690

Huang, Y.-M., Huang, T.-C., \& Hsieh, M.-Y. (2008). Using Annotation Services in a Ubiquitous Jigsaw Cooperative Learning. Educational Technology \& Society, 11(2), 3-15.

Kadirire, J. (2009). Mobile Learning DeMystified. The Evolution of Mobile Teaching and Learning, 15-55.

Kato, F. (1996). Results of an Australian study of strategy use in learning Japanese Kanji characters. University of Sydney, Sydney, Australia.

Keser, H., Uzunboylu, H., \& Ozdamli, F. (2012). The trends in technology supported collaborative learning studies in 21st century. World Journal On Educational Technology, 3(2), 103-119.

Kevin, C. C. (2014). The Positive Effects of Technology on Teaching and Student Learning. Retrieved from https://files.eric.ed.gov/fulltext/ED554557.pdf

Ku, P. N. (1995). Strategies Associated with Proficiency and Predictors of Strategy Choice: A Study of Language Learning Strategies of EFL Students at Three Educational Levels in Taiwan. Unpublished doctoral dissertation,Indiana University, Bloomington, Indiana, USA.

Kukulska-Hulme, A. (2005). Mobile Learning A Handbook for Educators and Trainers. London: Routledge.

Kukulska-Hulme, A., \& Shield, L. (2008). An overview of mobile assisted language learning: From content delivery to supported collaboration and interaction. ReCALL, 20(3), 271-289.

Laouris, Y., \& Eteokleous, N. (2005). We Need an Educational Relevent Difinition of mobile Learning. Paper Presented at the 4th World Conference on MLearning.

Le, H. (2018). Improve Students Engagement and Collaboration with Kahoot. TESOLconference2018.

Lickona, T. (1992). Educating for character: How our schools can teach respect and responsibility. New York, NY: Bantam Books.

Liu, H., \& Cain, william (Eds.). (2016). Investigating mobile assisted english foreign language learning and teaching in China: Issues, attitudes and perceptions. In wenhao Tao (Series Ed.), Investigating mobile assisted english foreign language learning and teaching in China: Issues, attitudes and perceptions. https://doi.org/10.4018/978-1-5225-0177-0

Low, L., \& O'Connell, M. (2006). Learner-centric design of digital mobile learning. Proceedings of the OLT Conference, 71-82.

Motiwalla, L. F. (2007). Mobile learning: A framework and evaluation. Computers \& Education, 49(3), 581-596.

Nguyen, H. T., \& Tran, N. M. (2015). Factors affecting students' speaking performance at Le Thanh Hien high school. Asian Journal of Educational Research, 3(2).
Nguyen, N. V. (2016). Mobile Learning in Language Teaching Context of Vietnam: An Evaluation of Students' Readiness. Ho Chi Minh National University of Education Science Journal, 7(85), 16-27.

O, K. M. (2015). The effectiveness of mobile assisted language learning on L2 listening comprehension. Multimedia-Assisted Language Learning, 18(2), 135-158.

O’Malley, C., Vavoula, G., Glew, J., Taylor, J., Sharples, M., Lefrere, P., Waycott, J. (2005). Guidlines for Learning/Teaching/Tutoring in a Mobile Environment. Public Deliverable from the MOBILearn Project.

Oxford, R. (1990). Language Learning Strategies: What Every Teacher Should Know. Boston: Heinle \& Heinle.

Oxford, R. (1999). Relationships between learning strategy use and language proficiency in the context of learner autonomy and self-regulation. Learner Autonomy as a Central Concept of Foreign Language Learning, 38, 109-126.

Oxford, R. (2003). Language learning styles and strategies: an overview. Gala, 1-25.

Oxford, R. (2011). Teaching \& Researching: Language Learning Strategies (1st ed.). Pearson Education.

Pachler, N., Bachmair, B., \& Cook, J. (2010). Mobile Learning. Structures, Agency, Practices. London: Springer.

Paul, R., \& Therese, L. (2007). Technology in Support of Collaborative Learning. Educational Psychology Review, 19, 65-83.

Quinn, C. (2000). mLearning: mobile, wireless, InYour-Pocket Learning. Linezine.

Scarcella, R., \& Oxford, R. (1992). The Tapestry of Language Learning: The Individual in the Communicative Classroom. Boston: Heinle \& Heinle.

Sila Ahmad, K., Armarego, J., \& Sudweeks, F. (2017). The Impact of Utilising Mobile Assisted Language Learning (MALL) on Vocabulary Acquisition among Migrant Women English Learners. Interdisciplinary Journal of E-Skills and Lifelong Learning, 13, 037057. https://doi.org/10.28945/3703

Stockwell, G. (n.d.). Using mobile phones for vocabulary activities: examining the effect of the platfor. Language Learning \& Technology, 14(2), 95-110.

Stockwell, G., \& Hubbard, P. (2013). Some emerging principles for mobile-assisted language learning. CA: The International Research Foundation for English Language Education.

Suwantarathip, O., \& Wichadee, S. (2014). The effects of collaborative writing activity using Google Docs on Students' writing abilities. TOJET: The Turkish Online Journal of Educational Technology, 13(2).

Taher, B., \& Tam, S. S. (2012). Informal Language Learning Setting: Technology or Social Interaction? TOJET: The Turkish Online Journal of Educational Technology, 11(2), 142-149. 
Tasdemir, M. (2010). The effects of the REAP reading comprehension technique on students' success. Social Behavior and Personality: An International Journal, 38, 553-560.

Turner, N (2012). What is mlearning? Retrieved on 20 July 2019 from https://aurionlearning.wordpress. com/2012/03/21/what-is-mlearning/

Van den Berg, H., Manstead, A., Van der Pligt, J., \& Wigboldus, D. (2006). The impact of affective and cognitive focus on attitude formation. Journal of Experimental Social Psychology, 42, 373-379.

Viberg, O., \& Grönlund, A. (2012). Mobile assisted language learning: A literature review. In 11th World Conference on Mobile and Contextual Learning.

Vishal, J. (2014). 3D Model of Attitude. International Journal of Advanced Research in Management and Social Sciences, 3(3).

Wang, Y. H., \& Shih, S. K. H. (2015). Mobileassisted language learning: Effects on EFL vocabulary learning. International Journal of Mobile Communications, 13(4), 358. https://doi. org/10.1504/IJMC.2015.070060

Wardlow, L. (2016). How technology can boost student engagement. Retrieved from https://www.pearsoned. com/technology-can-boost-student-engagement/
White, J., \& Mills, D. J. (2011). Get Smart!: Smartphones in the Japanese classroom. JALT Conference Proceedings-JALT2011, 36, 328-337.

Winters, N. (2006). What is mobile learning? Big Issues in Mobile Learning: Report of a Workshop by the Kaleidoscope Network of Excellence Mobile Learning Initiative. University of Birmingham.

Wise, S. L. (1985). The development and validation of a scale measuring attitudes toward statistics. Educational and Psychological Measurement, 45(2), 401-405.

Wong, L.-H., \& Looi, C.-K. (2010). Vocabulary learning by mobile-assisted authentic content creation and social meaning-making: Two case studies. Journal of Computer Assisted Learning, 26, 421-433. https://doi.org/10.1111/j.1365-2729.2010.00357.x

Yang, S. (2012). Exploring college students 'attitudes and self-efficacy of mobile learning. Turkish Online Journal of Educational Technology, 11(4), 148-154.

Zarzycka-Piskorz, E. (2016). Kahoot it or not? Can games be motivating in grammar? The Journal of Teaching Language with Technology, 3, 17-36.

Zhang, Y. (2016). The Impact of Mobile Learning on ESL Listening Comprehension. International Conference on Advanced Education and Management, 3.

\title{
HỌC NGOẠI NGŨ̉ VỚI SỰ HÕ̃ TRỢ CỦA THIẾT BI! DI ĐỘNG TẠI MỘT TRƯỜNG ĐẠI HỌC VIẸT NAM: THÁI ĐỘ CỦA SINH VIỀN
}

\author{
Phạm Thu Trà \\ Khoa Tiếng Anh, Đại học Su phạm Hà Nội, \\ Xuân Thủy, Cầu Giấy, Hà Nội, Việt Nam
}

Tóm tắt: Bài báo bàn luận đến thái độ của sinh viên tại một trường đại học về việc học ngoại ngữ với sự hỗ trợ của thiết bị di động. Bài báo sử dụng phương pháp nghiên cứu hỗn hợp, với bảng hỏi khảo sát là công cụ nghiên cứu chính. Kết quả từ dữ liệu định tính và định lượng cho thấy đa số sinh viên có thái độ tích cực với việc sử dụng thiết bị di động để học ngoại ngữ nói chung hay trong lớp học nói riêng. Từ đó, tác giả đưa ra khuyến nghị rằng việc học ngoại ngữ với sự hỗ trợ của thiết bị di động nên được chấp nhận như một đường hướng mới trong việc giảng dạy và học tiếng Anh. Bên cạnh đó, một số biện pháp cần được đưa ra để nâng cao trình độ kỹ thuật số của cả giáo viên và sinh viên.

Tù khóa: học ngoại ngữ với sự hỗ trợ của thiết bị di động (MALL), học tập di động (M-learning) 